\title{
Information System of Location-Based Advertising Ordering and SMS Targeted (SiPesat) at MDMedia
}

\author{
Lilyani Asri Utami ${ }^{1}$ \\ STMIK Nusa Mandiri \\ Jl. Damai No. 8 Warung Jati Barat (Margasatwa) \\ Jakarta Selatan \\ lilyani.lau@nusamandiri.ac.id
}

\author{
Suparni ${ }^{2}$ \\ Universitas Bina Sarana Informatika \\ J1. Kamal Raya No. 18, Ringroad Barat, \\ Cengkareng \\ suparni.spn@bsi.ac.id
}

\author{
Wulan Anggraeni ${ }^{3}$ \\ STMIK Nusa Mandiri \\ Jl. Damai No. 8 Warung Jati Barat (Margasatwa) \\ Jakarta Selatan \\ wulan.anggrainny@gmail.com
}

\begin{abstract}
The LBA (Location Based Advertising) and SMS Targeted ordering system on MDMedia is designed to provide facilities for sales and operations in handling campaign orders. The running process still uses the manual method, that is, the user completes the form and sent it via e-mail to the operation for the verification process. This business process is very ineffective given the large number of LBA and SMS Targeted orders that come every day without recording data campaigns. The system design method uses the waterfall method. Program implementation uses PHP language with a database using MySQL. The development of the LBA and SMS Targeted ordering information system is able to provide effective work, because it can be well organized during the ordering process and report submission.
\end{abstract}

Keywords - Information System; SMS; Location Based Advertising; Targeted

\section{INTRODUCTION}

Advertising is a form of communication to sell products that provide goods or services to the public. Moving ads based on Short Message Services (SMS), or commonly known as SMS Ads, are becoming a new trend for product owners, agents and marketers to connect with consumers. Operators provide the methods of advertising through SMS by utilizing the location (geolocation) on the gadget and user numbers, namely SMS LBA (Location Based Advertising) and SMS Targeted.

LBA SMS is an SMS advertisement sent to locations that have been targeted within a certain radius both indoors and outdoors. For example: malls, schools, campuses, apartments, airports, office buildings, highways, and others. SMS Targeted is an SMS advertisement that is aimed at active cellular telephone customers with a scale range of all cities (hometowns) in Indonesia. Target recipients of SMS can be profiled based on demographics and behavior, such as age, gender, use of pulses per month (ARPU), religion, type of handset, and others.

According to Ariansyah (2015: 151) Based on ITU (International Telecommunication Union) data in 2012 Indonesian cellular telephone customers numbered around 280 million. This big market opens the opportunity for SMS Advertising service providers to market these services, one of which is PT. Metra Digital Media (MDMedia) a subsidiary of Telkom Group. MDMedia has been in the mobile advertising world for more than 5 years and has worked with cellular operators, especially for LBA and SMS Targeted products.

In business processes in the Operations section are often constrained because the process is still manual or semi-computerized. LBA and SMS Targeted shows are required for a Campaign Order 
Form (FCO) containing the SMS campaign material. LBA and Targeted FCO templates use the excel form. Next, the FCO scan is sent via email to the Operations section. When the FCO is verified, it is often found several obstacles so that the process becomes ineffective and inefficient. Among the errors in filling, the schedule outside the provisions, the scan results are unclear, the administration file is incomplete, the delivery quota number does not match the standard, and others. In the end the client and sales person must revise the document and send an email again. This manual process is very time consuming and not efficient in using paper every time the FCO will be executed. Of course, it causes a lot of losses for the company if the SMS ad fails to appear or even found material errors due to the FCO are not well-documented. The company must pay more as compensation and the client's trust in service quality is reduced.

There is a possibility of negligence in handling the client campaign quota, this is because there is nothing to remind and there is no data recording. All documents are usually only stored in the local folder of each staff, data can be accessed by anyone because it is only a document on paper and there is no system of access rights, of course there is a risk of document loss and data theft.

The author intends to create a web-based LBA and SMS Targeted ordering information system at MDMedia. By using an online system, it will greatly facilitate business processes on the side of clients, sales and operations. Campaign bookings and delivery of reports become more organized, faster processed, Service Level Agreement (SLA) is more secure and will ultimately increase profits for the company.

\section{LiteratURE REVIEW}

Information system is a system in an organization that brings together the needs of daily transaction processing, supports managerial operations and strategy activities, provides certain outside parties with the necessary reports (Hutahaean, 2014: 13). Information systems are "a set of formal procedures where data is grouped, processed into information, and distributed to users" (Kadir, 2014: 9).

Mobile advertising is currently booming, because of the popularity of mobile devices. (Feng, Fu, \& Qin, 2016: 334). Mobile advertising enables retailers, service providers and manufacturers to offer consumers increasingly relevant offers (Grewal, Bart, Spann, \& Zubcsek, 2016: 3).

The waterfall model is often called the classic life cycle (classic life cycle). The waterfall model provides a sequential or sequential device life cycle starting from analysis, design, coding, testing, and supporting support. In this method, the structure of the system development stage is clear, documentation is generated at each stage of development, and a stage is carried out after the previous stage is completed (Sukamto and Shalahuddin, 2014: 28)

UML (Unified Modeling Language) as one standard language that is commonly used to define needs, make analysis and design, and describe architecture in object-oriented programming. A series of images and diagrams are provided by UML. Some diagrams exist which focus on the resilience of object-oriented theory and partly on the details of design and construction. This is intended as a means of communication between the program team and the user (Sukamto and Shalahuddin, 2014: 133)

Information system research using waterfall method has been done by many previous researches in various fields.

The reservation process at Hin's Hotel is experiencing many obstacles because the booking process is recorded in the reservation book, customers who want to book a room must come in person or by phone, the dissemination of information is still through newspapers, advertisements on the radio or brochures distributed. So an e-reservation application was made for room bookings at Hin's Hotel, which provides facilities for customers and hotel management in handling hotel bookings. The software development model used is the waterfall model. With the e-reservation application at Hin's Hotel Jakarta can provide information needed by guests and the hotel. For hotel management can increase the effectiveness of work bookings can be faster, more accurate and timely because the data processing is carried out by the system, and the data is stored in the database so it is safer, neat and maintained (Hidayatun, 2017).

In the world of education, web-based academic information systems use the waterfall method designed by SMK Yapipa Serpong Utara to facilitate schools in delivering academic information and can be accessed anytime and anywhere by teachers and students without being limited by distance and time using only one set of computers or smartphone connected to the internet (Nurajijah dan Indriani, 2017).

PT. Sakura Yasa Prima has a desire to utilize information technology through building an inventory system. The inventory system uses the FIFO (First In First Out) method to regulate the flow of goods in and out of the warehouse. The development of information systems processes 
inventory data with the waterfall model while the tool used is UML (Unified Modeling Language). The programming language uses PHP, and the MySQL database. This system is built in a user friendly manner, so it is equipped with an interface that is easy to understand and made as attractive as possible (Nawang, 2017).

\section{Proposed Method}

Based on the problems that have been described, the purpose of this research is how to design an information system or build an information system for LBA and SMS Targeted Ordering as MDMedia needs so that it is better documented and can improve the effectiveness and efficiency of work performance and business processes within the company, and can minimize the deficiencies that exist in the company today. In building this system, the author uses the Waterfall method. The stages in the waterfall method (Sukamto and Shalahuddin, 2014: 28) are:

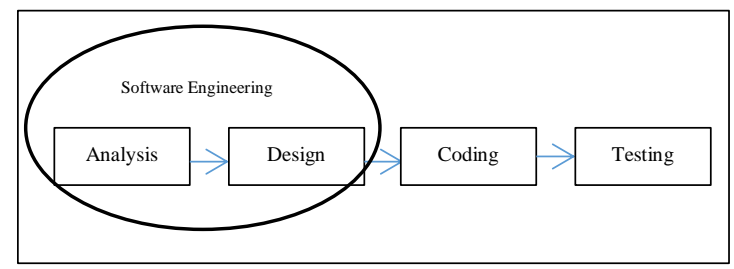

Figure 1. Stage Of Research

\section{A. System Requirements Analysis}

The author analyzes the requirements of the system and the user. The system created has two pages, namely the front end and back end which have different access rights. Front end has access rights to fill in order forms, add and cancel orders, upload administrative files, and view reports. Back end privileges such as view, add, delete, manage data and upload SMS report results. The data needed in designing the LBA and SMS Targeted ordering system on MDMedia is user data, customer data and SMS campaign data.

\section{B. Design}

In the process of making this LBA and SMS Targeted ordering system the writer uses the Yii Framework 2.0 and the database uses MySQL. Design uses Entity Relational Diagram (ERD) and Logical Relational Structure (LRS) and Unified Modeling Language (UML) design using Activity Diagrams, Use Case Diagrams, Class Diagrams, Sequence Diagrams, Component Diagrams and Deployment Diagrams. UML describes a model that can be understood and presented in the textual model of the programming language. The UML model can be connected directly to visual programming languages.

\section{Code Generation}

In this stage the author uses the development of object-oriented programs or Object Oriented Programs and translates the codes into the programming language PHP and the programming that is made is object-based programming.

\section{Testing}

The author tested the program to find out whether the program was running in accordance with the structure that had been created by attempting to use Blackbox Testing.

\section{E. Support}

To use the system that the author made, needed support in the form of hardware with the following specifications: Intel Core i3 $1.80 \mathrm{GHz}, 6.00 \mathrm{~GB}$ RAM, 15 inch monitor, standard keyboard and mouse. For software specifications as follows: Windows 8 Operating System, Internet Explorer Browser, Mozilla Firefox and Google Chrome. Stages of system maintenance covers all processes needed to ensure continuity, smoothness, and improvement of the system that has been operated

\section{RESUlt AND Discussion}

\section{A. Designing LBA and SMS Targeted Ordering Information System}

The information system model built using UML, which aims to visualize the system so that it can get an application system that is in accordance with what is needed.

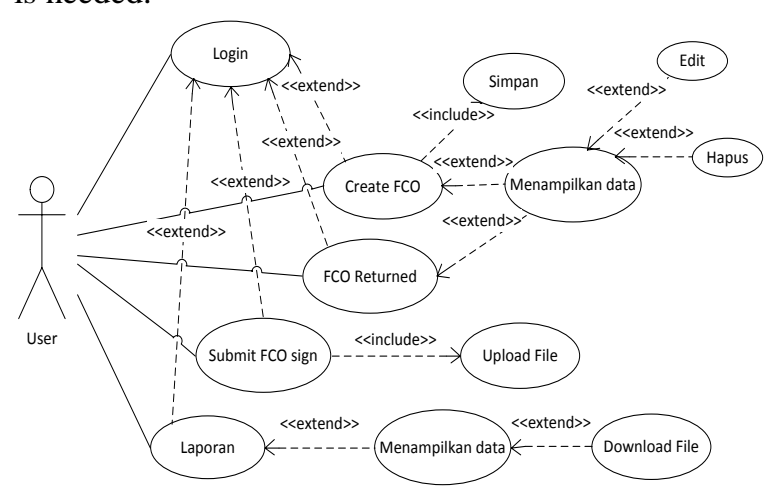

Figure 2. Use Case Diagram for Users

115

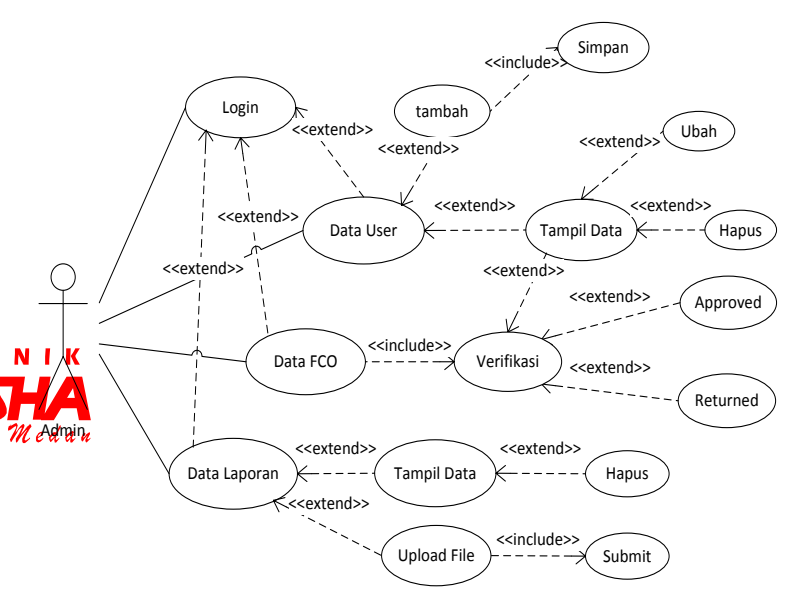


Figure 3. Use Case Diagram for Administrators

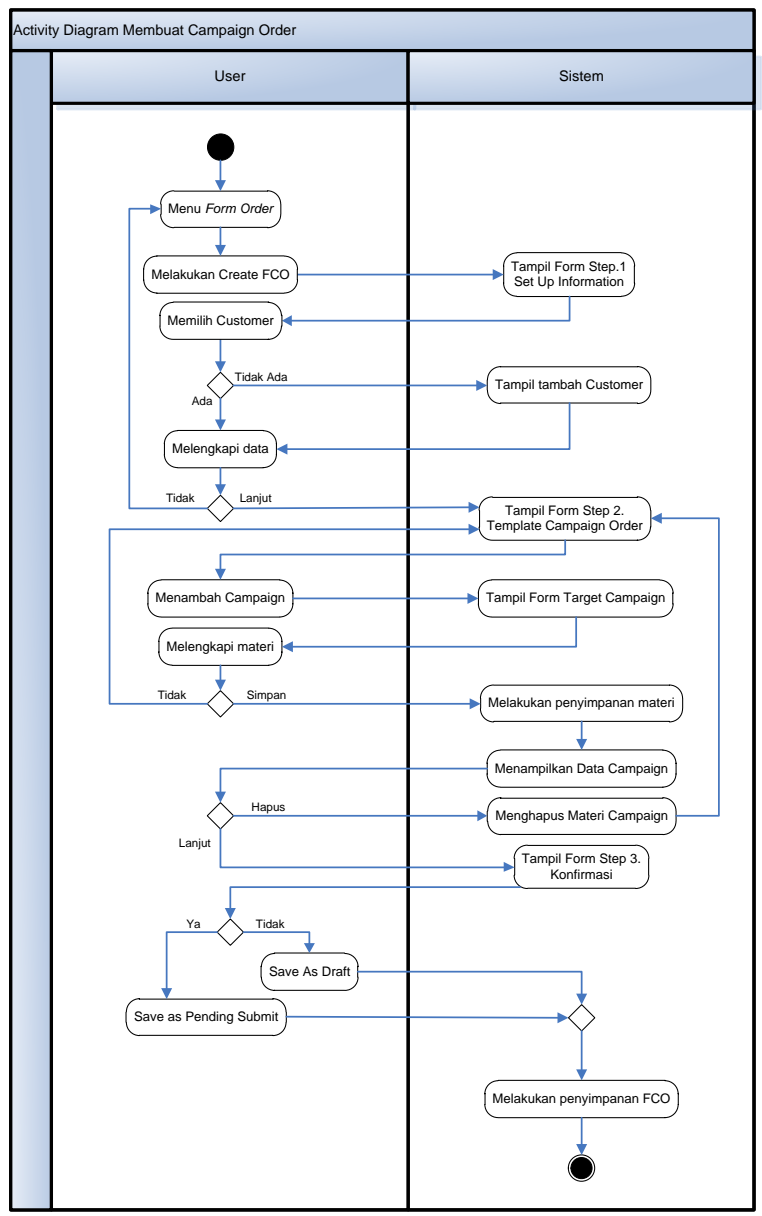

Figure 4. Activity Diagram User Creates a Campaign Order

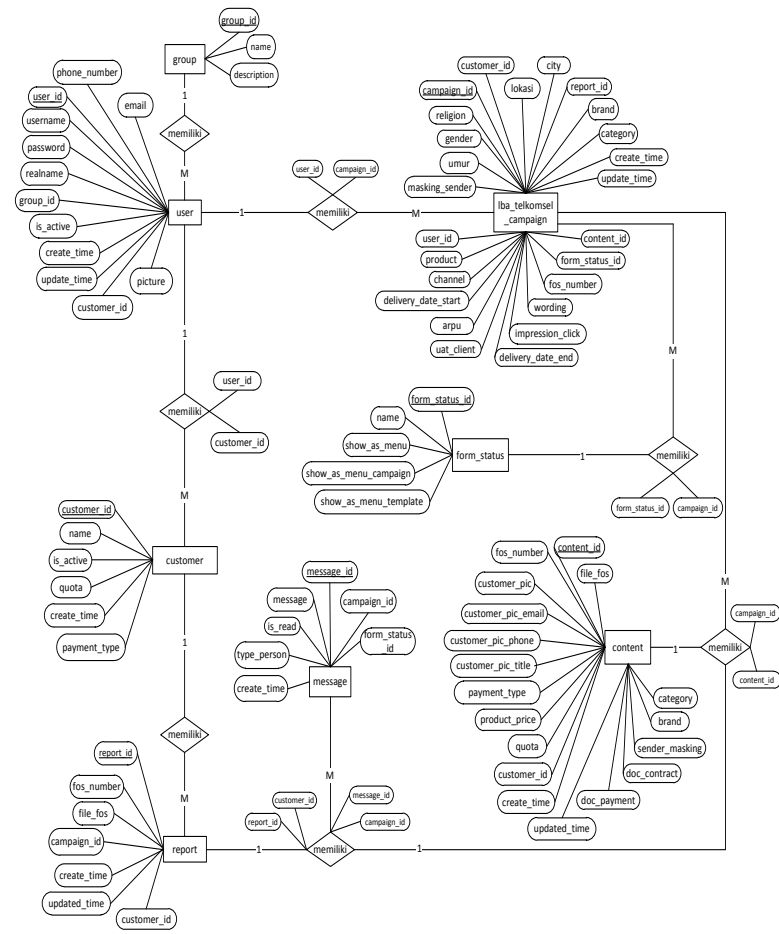

Figure 5. ERD of LBA and SMS Targeted Ordering Information System

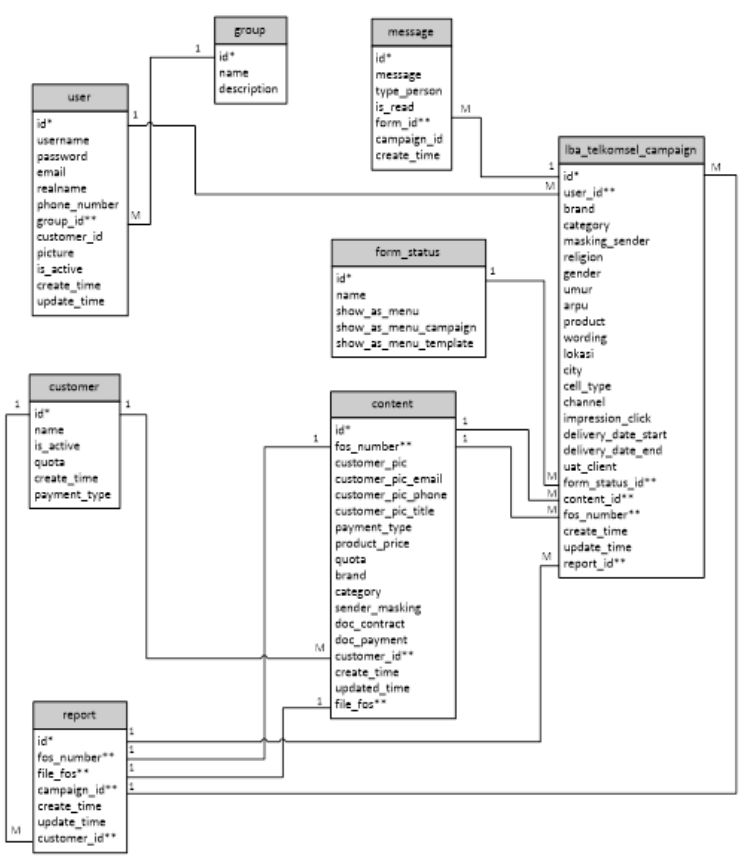

Figure 6. LRS of LBA and SMS Targeted Ordering Information System 


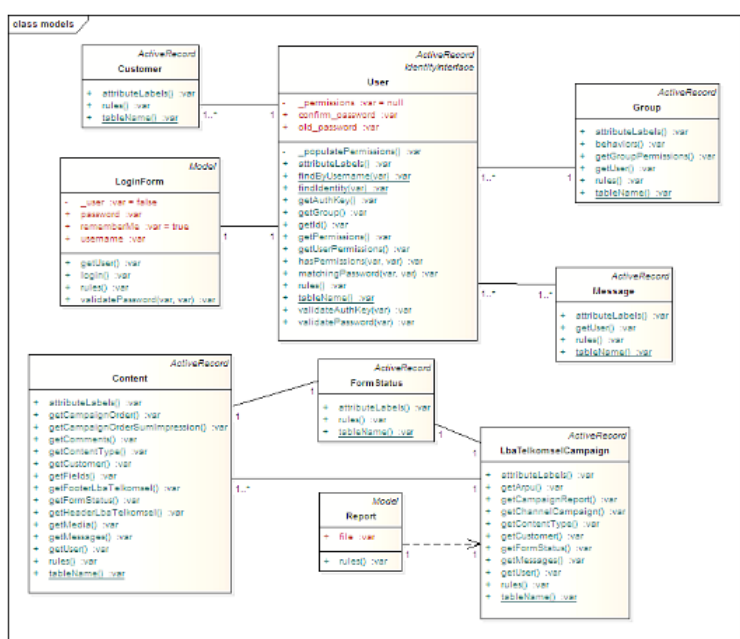

Figure 7. Class Diagram of LBA and SMS Targeted Ordering Information System

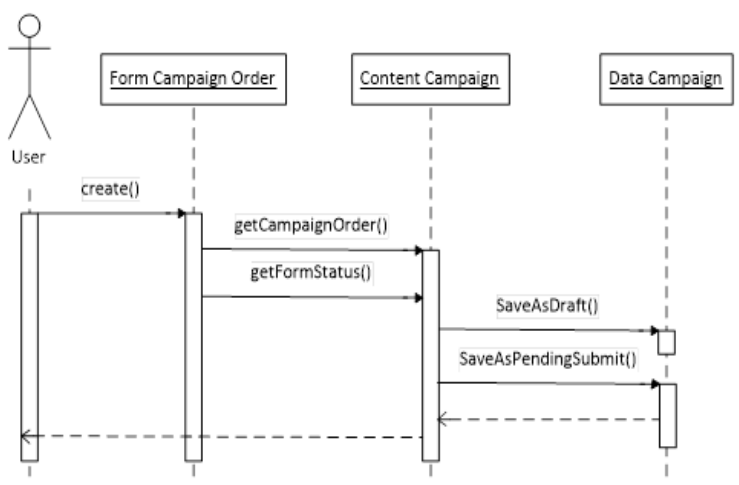

Figure 8. Sequence Diagram User Creates a Campaign Order

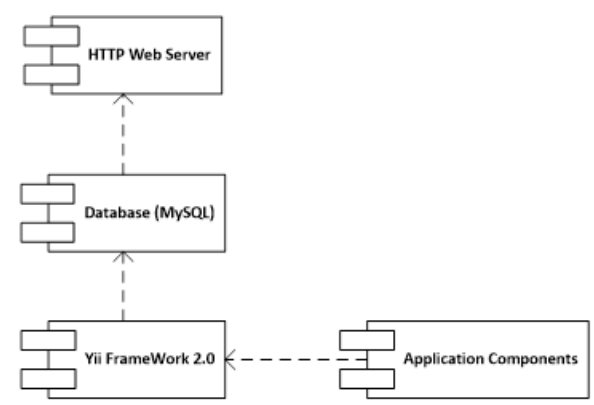

Figure 9. Component Diagram of LBA and SMS Targeted Ordering Information System

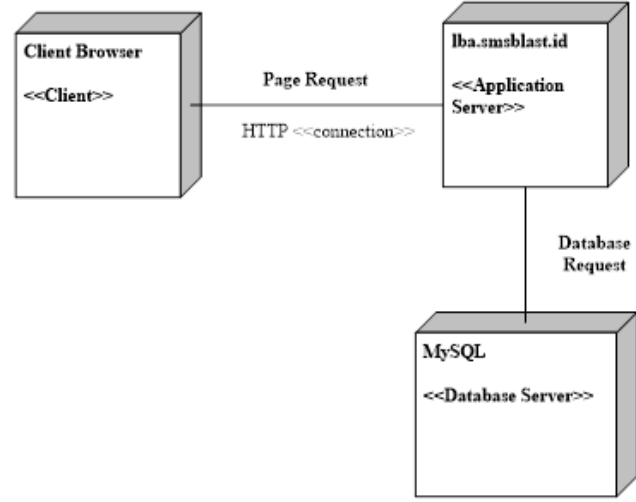

Figure 10. Deployment Diagram of LBA and SMS Targeted Ordering Information System

B. User Interface Design of LBA and SMS Targeted Ordering Information System

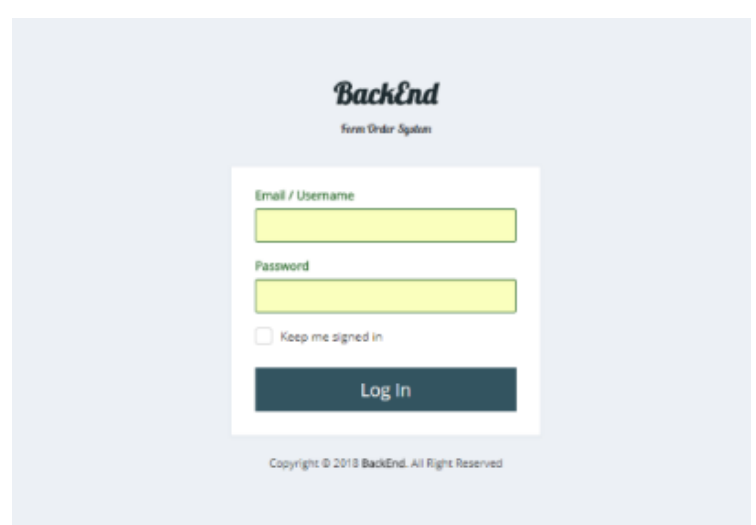

Figure 11. Display of Login Pages

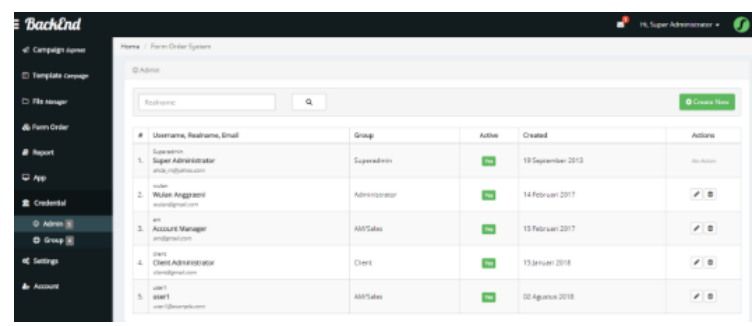

Figure 12. Display of the User Form 


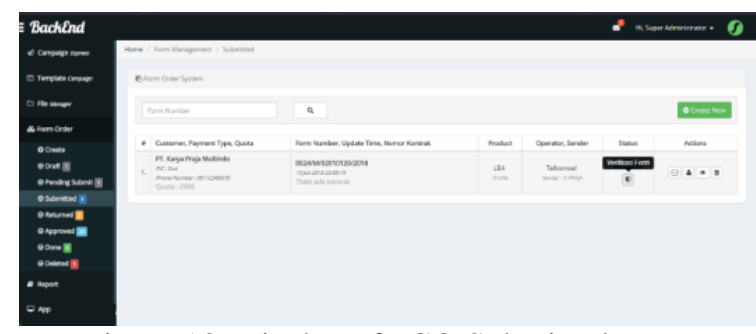

Figure 13. Display of FCO Submitted Form

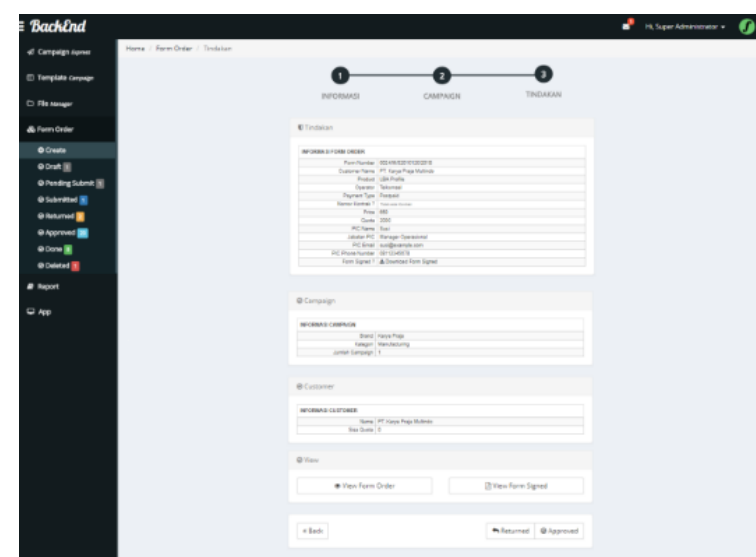

Figure 14. Display of FCO Verification Form

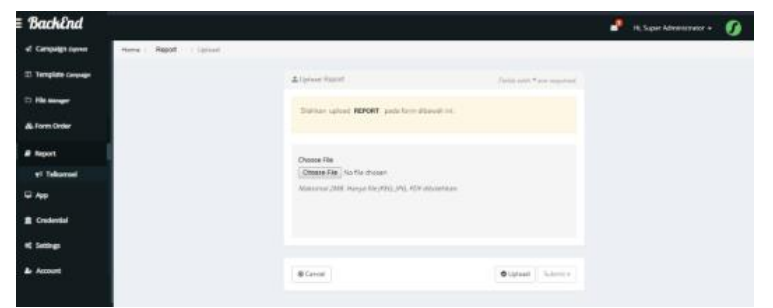

Figure 15. Display of Report Submission Form

\section{Testing}

System testing is done using the black box testing method. Tests are carried out to determine whether the program designed is running well or there are still errors

\begin{tabular}{|l|l|l|l|l|l|}
\hline No. & Skenario Pengujian & Test Case & Hasil yang Diharapkan & $\begin{array}{l}\text { Hasil } \\
\text { Pengujian }\end{array}$ & Kesimpulan \\
\hline 1 & $\begin{array}{l}\text { Klik tombol pada } \\
\text { FCO yang ingin } \\
\text { dihapus }\end{array}$ & $\begin{array}{l}\text { Klik tombol } \\
\text { view }\end{array}$ & $\begin{array}{l}\text { Sistem menampilkan } \\
\text { Form Campaign Order }\end{array}$ & $\begin{array}{l}\text { Sesuai } \\
\text { harapan }\end{array}$ & Valid \\
\hline 2 & $\begin{array}{l}\text { Klik tombol delete } \\
\text { pada FCO yang } \\
\text { ingin dihapus }\end{array}$ & $\begin{array}{l}\text { Klik tombol } \\
\text { delete }\end{array}$ & $\begin{array}{l}\text { Sistem menghapus data } \\
\text { Form Campaign Order }\end{array}$ & $\begin{array}{l}\text { Sesuai } \\
\text { harapan }\end{array}$ & Valid \\
\hline 3 & $\begin{array}{l}\text { Klik tombol } \\
\text { download form } \\
\text { pada FCO yang } \\
\text { ingin dihapus }\end{array}$ & $\begin{array}{l}\text { Klik tombol } \\
\text { download }\end{array}$ & $\begin{array}{l}\text { Sistem menampilkan } \\
\text { Form Campaign Order } \\
\text { dan bisa diunduh }\end{array}$ & $\begin{array}{l}\text { Sesuai } \\
\text { harapan }\end{array}$ & Valid \\
\hline 4 & $\begin{array}{l}\text { Klik tombol upload } \\
\text { form signed pada } \\
\text { FCO yang ingin di } \\
\text { upload }\end{array}$ & $\begin{array}{l}\text { Klik tombol } \\
\text { upload }\end{array}$ & $\begin{array}{l}\text { Sistem masuk ke } \\
\text { halaman upload dan } \\
\text { bisa choose file yang } \\
\text { sesuai }\end{array}$ & $\begin{array}{l}\text { Sesuai } \\
\text { harapan }\end{array}$ & Valid \\
\hline
\end{tabular}

Figure 16. Black Box Testing of FCO Sign Form

\begin{tabular}{|l|l|l|l|l|l|}
\hline No. & Skenario Pengujian & Test Case & Hasil yang Diharapkan & $\begin{array}{l}\text { Hasil } \\
\text { Pengujian }\end{array}$ & Kesimpulan \\
\hline 1 & $\begin{array}{l}\text { Klik tombol view } \\
\text { message pada FCO } \\
\text { yang dipilih }\end{array}$ & $\begin{array}{l}\text { Klik tombol } \\
\text { view message }\end{array}$ & $\begin{array}{l}\text { Sistem menampilkan } \\
\text { pesan review dari } \\
\text { Operasional }\end{array}$ & $\begin{array}{l}\text { Sesuai } \\
\text { harapan }\end{array}$ & Valid \\
\hline 2 & $\begin{array}{l}\text { Klik tombol delete } \\
\text { pada FCO yang } \\
\text { ingin dihapus }\end{array}$ & $\begin{array}{l}\text { Klik tombol } \\
\text { delete }\end{array}$ & $\begin{array}{l}\text { Sistem menghapus } \\
\text { data Form Campaign } \\
\text { Order }\end{array}$ & $\begin{array}{l}\text { Sesuai } \\
\text { harapan }\end{array}$ & Valid \\
\hline 3 & $\begin{array}{l}\text { Klik tombol view } \\
\text { pada FCO yang } \\
\text { ingin dilihat }\end{array}$ & $\begin{array}{l}\text { Klik tombol } \\
\text { view }\end{array}$ & $\begin{array}{l}\text { Sistem menampilkan } \\
\text { Form Campaign } \\
\text { Order }\end{array}$ & $\begin{array}{l}\text { Sesuai } \\
\text { harapan }\end{array}$ & Valid \\
\hline 4 & $\begin{array}{l}\text { Klik tombol update } \\
\text { informasi pada }\end{array}$ & $\begin{array}{l}\text { Klik tombol } \\
\text { update } \\
\text { FCO yang ingin } \\
\text { diubah }\end{array}$ & $\begin{array}{l}\text { Sistem menampilkan } \\
\text { Form Campaign step } \\
\text { inform }\end{array}$ & $\begin{array}{l}\text { Sesuai } \\
\text { harapan }\end{array}$ & Valid \\
\hline 5 & $\begin{array}{l}\text { Klik tombol update } \\
\text { campaign pada }\end{array}$ & $\begin{array}{l}\text { Klik tombol } \\
\text { update } \\
\text { FCO yang ingin } \\
\text { campaign } \\
\text { ciubah }\end{array}$ & $\begin{array}{l}\text { Sistem menampilkan } \\
\text { Form Campaign step } \\
\text { 2.materi campaign }\end{array}$ & $\begin{array}{l}\text { Sesuai } \\
\text { harapan }\end{array}$ & Valid \\
\hline
\end{tabular}

Figure 17. Black Box Testing of FCO Revision Form

\section{CONCluSion ANd SugGestion}

Conclusions that can be drawn from this study are as follows:

1. By using this system, the ordering process that occurs between the Client / Sales and Operations will be well organized when the order process takes place and the process of submitting campaign reports, so that the business process runs more effectively and efficiently.

2. With this system, it can facilitate the Sales team in seeing the status of campaign orders that have been made, so that if a campaign is approved or not approved it will be easier to know and track its history.

3. This system also reduces errors in filling out the campaign order form.

Suggestions in developing information systems for LBA and SMS Targeted Ordering, among others:

1. The development of this system is expected to be more complex, especially in the reporting section, the summary traffic can be displayed, so that the balance of the Client's SMS quota can be fulfilled.

2. The development of this system is expected to be sustainable with other internal systems, such as accounting applications, project management, and others so that it can complete reports relating to company performance.

3. The system user must fulfill all the procedures required by the system to implement this campaign ordering information system.

\section{REFERENCES}

Ariansyah, K. (2015). Proyeksi Jumlah Pelanggan Telepon Bergerak Seluler di Indonesia. Buletin Pos Dan Telekomunikasi, 12(2), 151. https://doi.org/10.17933/bpostel.20104.120206

Feng, X., Fu, S., \& Qin, J. (2016). Determinants of consumers' attitudes toward mobile advertising: 
The mediating roles of intrinsic and extrinsic motivations. Computers in Human Behavior, 63 , 334-341.

https://doi.org/10.1016/j.chb.2016.05.024

Grewal, D., Bart, Y., Spann, M., \& Zubcsek, P. P. (2016). Mobile Advertising: A Framework and Research Agenda. Journal of Interactive Marketing, 34, 3-14. https://doi.org/10.1016/j.intmar.2016.03.003

Hidayatun, N., Rosmiati, M., \& Saputro, E. (2017). Aplikasi E-Reservation Untuk Pemesanan Kamar Pada Hotel Hin'S. Jurnal Techno Nusa Mandiri, 14(1), 57-62. Retrieved from http://ejournal.nusamandiri.ac.id/ejurnal/index. php/techno/article/view/401/308

Hutahaean, Jeperson. 2014. Konsep Sistem Informasi. Edisi 1, Cetakan.1 Yogyakarta : Deepublish.

Kadir, Abdul. 2014. Pengenalan Sistem Informasi Edisi Revisi. Yogyakarta : Andi Offset.
Nawang, M., Kurniawati, L., \& Duta, D. (2017). Rancang Bangun Sistem Informasi Pengolahan Data Persediaan Barang Berbasis Dekstop Dengan Model Waterfall. Jurnal Pilar Nusa Mandiri, 13(2), 233-238. Retrieved from http://ejournal.nusamandiri.ac.id/ejurnal/index. php/pilar/article/view/700

Nurajijah, \& Indriani, K. (2017). Implementasi Model Waterfall Pada Pembangunan Sistem Informasi Akademik Berbasis Web Pada SMK Yapipa Serpong Utara. Techno Nusa Mandiri, 14(2), 77-82. Retrieved from http://ejournal.nusamandiri.ac.id/ejurnal/index. php/techno/article/view/480

Sukamto, Rosa A. dan M. Salahuddin. 2014. Rekayasa Perangkat Lunak Terstruktur dan Berorientasi Objek. Bandung: Informatika. 